\title{
Sustainable Development of Agriculture in Russian Regions on the Basis of Inclusiveness
}

\author{
Vadim DEMICHEV \\ Russian State Agrarian University - Moscow Timiryazev Agricultural Academy, Moscow, Russia; \\ vadi.demiche@mail.ru
}

\begin{abstract}
The main objectives of the study are to formulate the concept of inclusive development of the Russian agricultural economy, develop a system of indicators for inclusive development, and assess the level and key patterns of inclusive development of agriculture in Russian regions. The article considers the relevance of the inclusive model of development of the Russian agricultural economy, defines the inclusive development of the agricultural economy, and develops a system of indicators for evaluating inclusive development. The index of inclusive green growth is calculated on the basis of the presented system of indicators. Based on the grouping of regions by the index value, the inverse relationship between the development of agriculture and emerging problems in the field of environmental protection is revealed. Based on the results of the study, the following conclusions can be drawn: Russian agriculture is developing unevenly both regions and types of producers, a new approach to economic growth is needed, inclusive development will involve all regions and types of producers in the growth, the green inclusive growth index is a suitable measure for new quality growth, development of agriculture on the basis of inclusiveness will provide economic green growth, reduction of poverty and injustice.
\end{abstract}

Keywords: agriculture economy; rural areas; inclusiveness; inclusive green growth index; sustainability; indicators of inclusive development

JEL Classification: P32; O4; R3

\section{Introduction}

Despite the fact that agriculture is the most dynamically developing sector of the Russian economy (agricultural - on average 3.2\% annually, economy - on average 2.2\% annually for the last 15 years) and the production of agricultural products has increased by $50 \%$. There are some issues in agriculture that make inclusiveness significant. Firstly, only one-third of Russian regions have increased the growth of the agricultural economy. It means that almost $70 \%$ of Russian regions have decreased agricultural production (Zinchenko 2016). Not at all regions included in growth. Secondly, governmental subsidies are distributed unevenly across the regions. And the government supports mainly the large investment projects. 


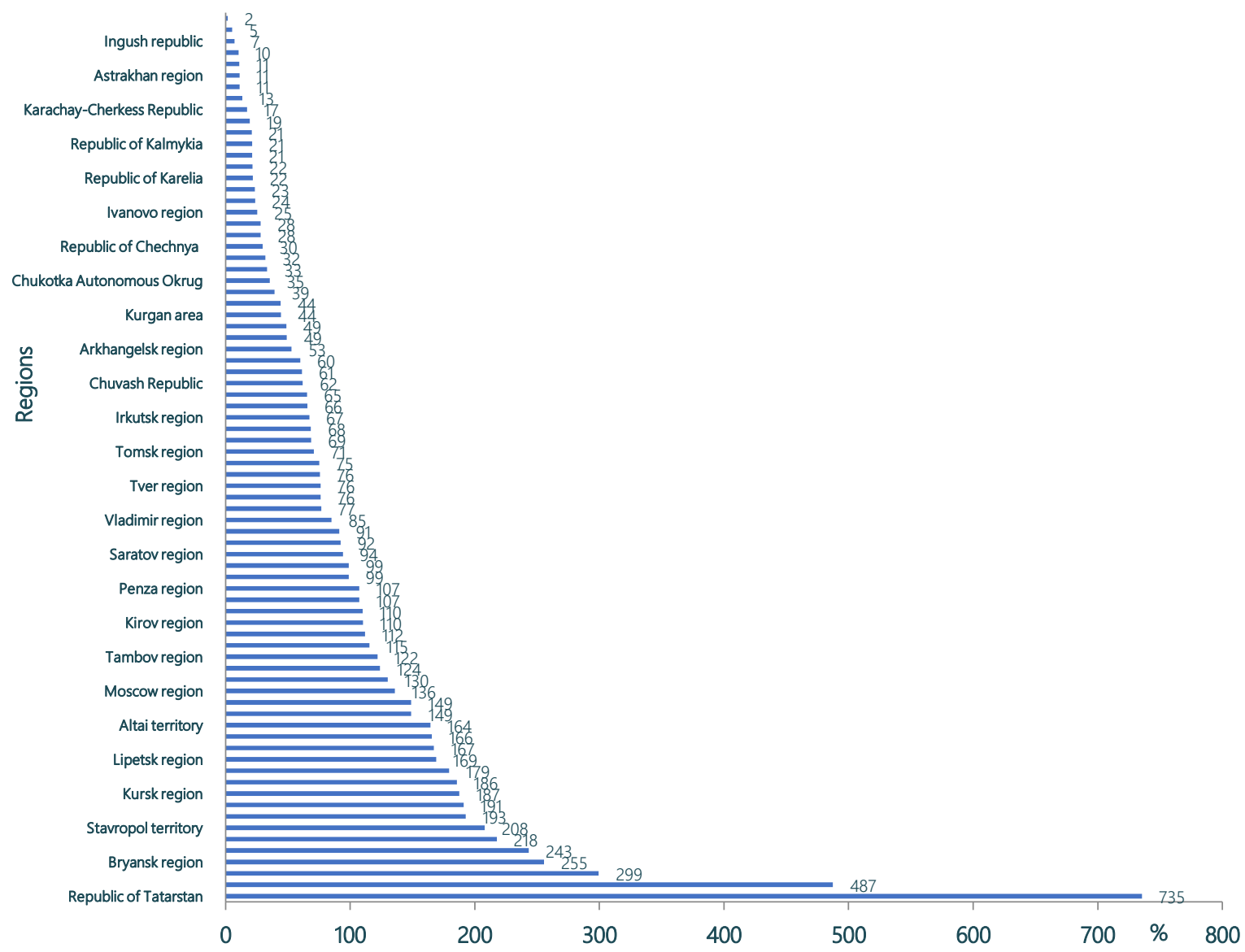

Figure 1. The ratio of agricultural subsidies in the region to the average for all regions (the amount for the period from 2006 to 2017.

This is subsidies in the exact region divided by the average value of subsidies in a whole population of regions. We can say that $50 \%$ of budget subsidies fall on 15 Russian regions (out of 85 regions). As you can see some regions receive budget subsidies more than others. It helps them to modernize and to raise agricultural production. The government support directs mainly in large projects, large agricultural organizations because they have more opportunities to get government support. We can draw a conclusion about this from the data in Table 1.

Table 1. Share of organizations, peasant (farm) households and individual businessman received credit funds and subsidies, $\%$ of their total number.

\begin{tabular}{ccc}
\hline Enterprises of all types & Credit funds & Subsidies (grants) \\
\hline Agricultural organizations & 24.6 & 68.8 \\
Including: Large and medium-sized organizations & 37.4 & 75.5 \\
Small organizations & 20.4 & 66.6 \\
Peasant (farm) households & 10.7 & 34.5 \\
Including: Peasant (farm) households & 11.7 & 39.0 \\
Individual businessman & 6.9 & 18.4 \\
\hline
\end{tabular}

In Russia, agricultural products produce four tapes of producers - agricultural organizations, peasant (farm) households, individual businessmen and households of citizens. 
The table shows that $37 \%$ of large and medium-sized organizations receive credits while only $6.9 \%$ of individual businessmen get credits. It is the same as subsidies. Almost $76 \%$ of large and medium-sized organizations receive subsidies and just $18 \%$ of individual businessmen get credits. In other words, organizations and other type's producers have different opportunities for development (Demichev 2019).

To make Russian food security more sustained there is a need to support peasant (farm) households, individual businessmen and households of citizens as a parallel alternative of the large producers, including studying the experience of other countries (Cheng et al. 2018, Berkhout et al. 2018, Mdee et al. 2019). Thus, there is a chance to promote the development of a new model of agricultural growth. And it can be the model of inclusive development.

\section{Methodology}

The study used General scientific methods of induction and deduction, analysis and synthesis. The following methodology was used to build the inclusive green growth index (Inclusive green growth index 2018):

The scores are converted to a $1-6$ scale (worst to best):

$$
\begin{aligned}
& 5 \times \frac{((\text { country score }- \text { sample minimum }))}{((\text { sample maximum }- \text { sample minimum }))}+1 \text { (positive impact) } \\
& -5 \times \frac{((\text { country score }- \text { sample minimum }))}{((\text { sample maximum }- \text { sample minimum }))}+6 \text { (negative impact) }
\end{aligned}
$$

The indicators for each group are assigned equal weights and aggregated to compute the group scores.

IGGI of $\mathrm{AE}=1 / 3$ (Indicators of Economic growth) $+1 / 3$ (Social justice) $+1 / 3$ (Sustainability of the natural environment).

We have to do it in order to normalize our data. IGGI of AE was constructed across 78 Russian regions based on 2017 data.

Based on the calculated rating, the number of Russian regions were divided by the level of inclusive development of the agricultural economy. The regions were divided into groups according to the following principle:

$$
h=\frac{((\text { max value of index }- \text { min value of index }))}{\sqrt{\text { number }} \text { of regions }}
$$

The first group is from min value of the index $+h$, the second one is min value of the index $+2 h, \ldots$, the eighth one is from min value of the index $+8 \mathrm{~h}$. According to the value of the index, each region fell into a particular group in terms of the level of inclusivity development.

The study used official statistics from the Ministry of Agriculture of Russia and the Federal state statistics service of Russia.

\section{Results}

\subsection{The Definition and System of Indicators of Inclusive Development Agricultural Economy}

Inclusive development of agriculture is ensuring equal access to economic opportunities of development for all agricultural producers and interaction between producers and rural area population.

Inclusiveness is able to solve such problems as inequality of opportunities for all types of producers, regional differentiation, poverty in rural areas, the gap in living standards between urban and rural areas, the decrease in rural population. There is a need to measure the different aspects of the new model of growth (Demichev 2018), including using best international experience and practice (Inclusive development index 2018; Sun et al. 2020). It is possible to do a basis on the system of indicators that can be integrated into IGGI of AE.

There are three groups of indicators - economic growth, social justice and sustainability of the natural environment. All of these indicators refer to inclusiveness and enable the achievement of SDGs. 
The first group of indicators reflects economic performance, economic sustainability, necessity to reduce concentration and diversification of producers. Economic performance and sustainability are fundamental for inclusive growth, as this provides the basis for creating expanding economic opportunities. The decrease in the concentration of production helps to overcome the consolidation of land in the possession of one owner. Diversification of producers enables us to save business diversity (Chiengkul 2019). A whole list of these indicators closely interacts with the second group.

Table 2. Mapping indicators of inclusive development of agriculture to elements of inclusiveness and SDG goals.

\begin{tabular}{|c|c|c|c|}
\hline $\begin{array}{l}\text { Group of } \\
\text { indicators }\end{array}$ & Indicator (Description) & $\begin{array}{l}\text { Elements of } \\
\text { inclusiveness }\end{array}$ & SDG goals \\
\hline 1 & 2 & 3 & 4 \\
\hline \multirow{6}{*}{$\begin{array}{l}\text { Economic } \\
\text { growth }\end{array}$} & $\begin{array}{l}\text { Gross value added of agriculture per } \\
\text { capita, rubles }\end{array}$ & $\begin{array}{l}\text { Economic } \\
\text { performance }\end{array}$ & No poverty \\
\hline & $\begin{array}{l}\text { Coefficient of variation of agricultural } \\
\text { production growth, \% }\end{array}$ & $\begin{array}{c}\text { Economic } \\
\text { sustainability }\end{array}$ & $\begin{array}{l}\text { Decent work } \\
\text { and economic } \\
\text { growth }\end{array}$ \\
\hline & $\begin{array}{c}\text { The average number of agricultural } \\
\text { organizations per } 1000 \text { hectares of } \\
\text { arable }\end{array}$ & $\begin{array}{l}\text { The decrease in } \\
\text { the concentration }\end{array}$ & $\begin{array}{l}\text { Industry, } \\
\text { innovation and } \\
\text { infrastructure }\end{array}$ \\
\hline & $\begin{array}{l}\text { Hirschman-Herfindahl Production } \\
\text { Concentration Index (cereals, potatoes, } \\
\text { vegetables, livestock, milk) by } \\
\text { enterprises of all types }\end{array}$ & $\begin{array}{l}\text { Diversification of } \\
\text { producers }\end{array}$ & $\begin{array}{l}\text { Responsible } \\
\text { consumption } \\
\text { and production }\end{array}$ \\
\hline & $\begin{array}{c}\text { An average level of profitability for the } \\
\text { last five years, } \%\end{array}$ & $\begin{array}{c}\text { Economic } \\
\text { sustainability }\end{array}$ & $\begin{array}{l}\text { Decent work } \\
\text { and economic } \\
\text { growth }\end{array}$ \\
\hline & $\begin{array}{l}\text { An average level of debt per } 1 \text { ruble of } \\
\text { agricultural productions, rubles }\end{array}$ & $\begin{array}{c}\text { Economic } \\
\text { sustainability }\end{array}$ & $\begin{array}{l}\text { Decent work } \\
\text { and economic } \\
\text { growth }\end{array}$ \\
\hline \multirow{5}{*}{$\begin{array}{l}\text { Social } \\
\text { justice }\end{array}$} & $\begin{array}{l}\text { The ratio of wages in agriculture to } \\
\text { wages in the economy as a whole, } \%\end{array}$ & Access to income & $\begin{array}{c}\text { Reduced } \\
\text { inequalities } \\
\text { Decent work }\end{array}$ \\
\hline & $\begin{array}{l}\text { Change in the number of people } \\
\text { employed in agriculture, } \%\end{array}$ & Access to work & $\begin{array}{l}\text { Sustainable city } \\
\text { and } \\
\text { communities }\end{array}$ \\
\hline & Employment rate of rural population, $\%$ & Access to work & $\begin{array}{l}\text { Sustainable city } \\
\text { and } \\
\text { communities }\end{array}$ \\
\hline & The change in the rural population, $\%$ & $\begin{array}{l}\text { Well-being } \\
\text { The preservation } \\
\text { of the rural } \\
\text { population }\end{array}$ & $\begin{array}{l}\text { Good health and } \\
\text { well-being }\end{array}$ \\
\hline & $\begin{array}{c}\text { Share of the rural population, in the age } \\
\text { from } 20 \text { to } 39 \text { years old having higher } \\
\text { education, } \%\end{array}$ & $\begin{array}{c}\text { Access to } \\
\text { education } \\
\text { Decent standards } \\
\text { of living }\end{array}$ & $\begin{array}{l}\text { Quality } \\
\text { education }\end{array}$ \\
\hline
\end{tabular}


Table 3. Mapping indicators of inclusive development of agriculture to elements of inclusiveness and SDG goals (Continuation).

\begin{tabular}{|c|c|c|c|}
\hline 1 & 2 & 3 & 4 \\
\hline \multirow{5}{*}{$\begin{array}{l}\text { Sustainabi } \\
\text { lity of the } \\
\text { natural } \\
\text { environm } \\
\text { ent }\end{array}$} & $\begin{array}{c}\text { The methane emission coefficients from } \\
\text { cows in the region, kilograms per cow } \\
\text { annually }\end{array}$ & $\begin{array}{l}\text { Reduction } \\
\text { potential impact } \\
\text { of climate change }\end{array}$ & $\begin{array}{c}\text { Sustainable city } \\
\text { and } \\
\text { communities } \\
\text { Climate action }\end{array}$ \\
\hline & $\begin{array}{l}\text { The methane emission coefficients from } \\
\text { other cattle in the region, kilograms per } \\
\text { cow annually }\end{array}$ & $\begin{array}{l}\text { Reduction } \\
\text { potential impact } \\
\text { of climate change }\end{array}$ & $\begin{array}{c}\text { Sustainable city } \\
\text { and } \\
\text { communities } \\
\text { Climate action }\end{array}$ \\
\hline & $\begin{array}{c}\text { The costs of protecting the land per } \\
1000 \text { rubles gross value added of } \\
\text { agriculture, rubles }\end{array}$ & $\begin{array}{l}\text { Careful } \\
\text { environmental } \\
\text { management }\end{array}$ & $\begin{array}{l}\text { Clean water and } \\
\text { sanitation }\end{array}$ \\
\hline & $\begin{array}{l}\text { Investment in environmental protection } \\
\text { for the last five years per } 1000 \text { rubles } \\
\text { gross value added of agriculture, rubles }\end{array}$ & $\begin{array}{l}\text { Careful } \\
\text { environmental } \\
\text { management }\end{array}$ & Life on land \\
\hline & $\begin{array}{l}\text { Air pollution by agriculture, according } \\
\text { to Government Report }\end{array}$ & $\begin{array}{l}\text { Reduction of air } \\
\text { pollution }\end{array}$ & $\begin{array}{l}\text { Sustainable city } \\
\text { and } \\
\text { communities }\end{array}$ \\
\hline
\end{tabular}

Economic growth does not necessarily involve the participation of a broad range of people and even areas. A growth is succeeding if all participants have the same opportunities to get income, work, education (Cobham and Klees 2016), well-being and high level of live standards. All of the social justice indicators illustrate it. The last indicator reflects the question of how many young and educated people rural areas have. It is essential because of this type of citizen the readiest to develop and create something new, something innovative.

The potential impact of climate change is measured in terms of methane emission from cows and other cattle. The costs of protecting and investing in environmental protection show careful environmental management as an essential element of sustainability of the natural environment (Green Growth Knowledge Platform 2013).

The level of air pollution is measured according to the government report about air pollution by agriculture. If there is the air pollution, we put 1 , if not, we put 0 . 


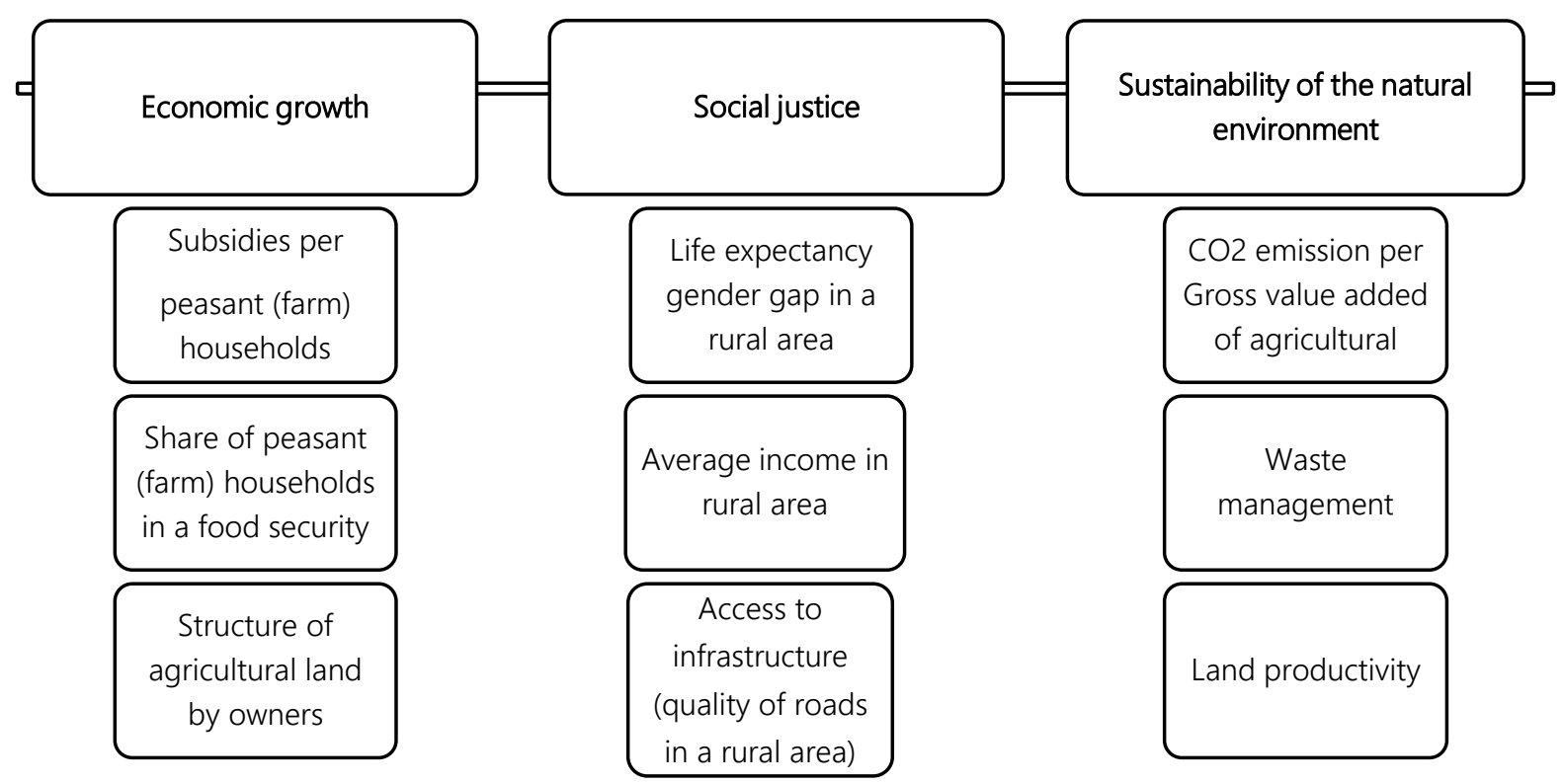

Figure 2. Indicators that were not constructed because of lack of data.

The system of indicators, however, does not cover important aspects of inclusiveness of agriculture (Figure 2) such as subsidies per peasant (farm) households, share of peasant (farm) households in a food security, structure of agricultural land by owners, life expectancy gender gap in a rural area, average income in rural area, access to infrastructure (quality roads in rural area), $\mathrm{CO} 2$ emission per GVA of agricultural, waste management, land productivity because of lack of data. And these are not all indicators that can be used in calculating the inclusive green growth index (Ginige et al. 2018; Struik and Kuyper 2017; Van Vuuren 2017; Ziankova et al. 2019). In addition, this system of indicators should be further improved by studying the factors that affect the modern economy and climate (The New Climate Economy Report 2018).

\subsection{Inclusive Green Growth Index of the Agricultural Economy in Regions of Russia}

Now we have to turn to the system of indicators. Using three groups of indicators (16 indicators) and using the methodology of the Asian Development Bank enable to construct Inclusive Green Growth Index.

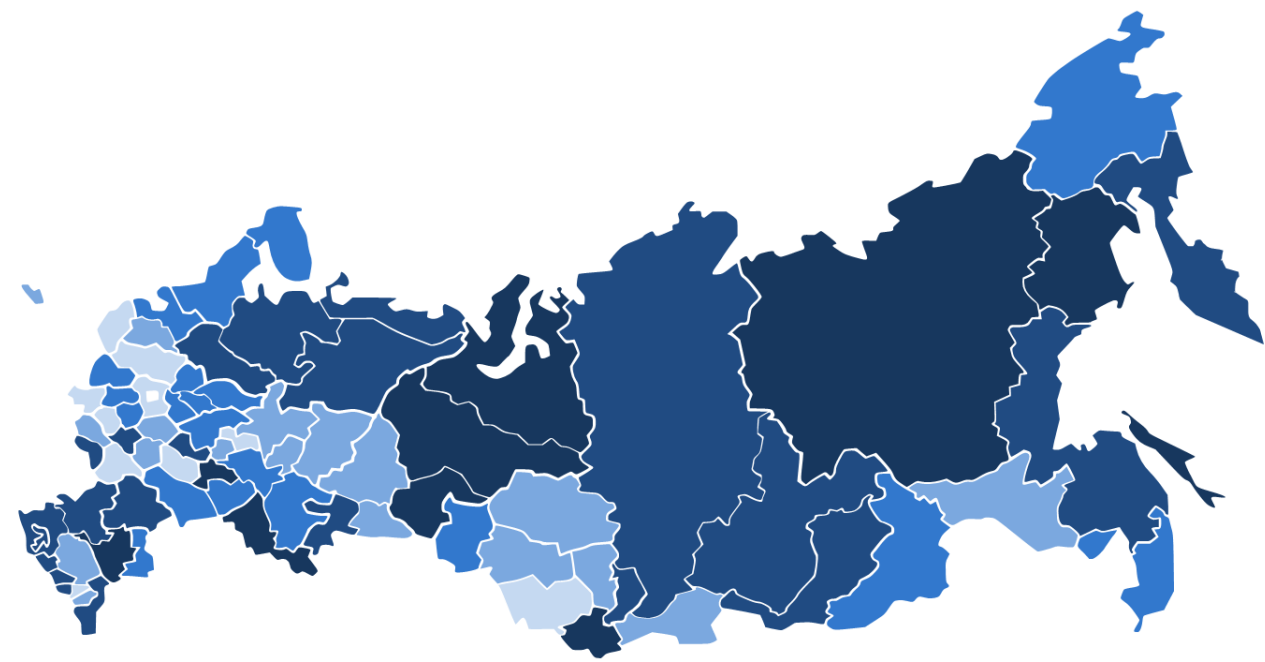

Figure 3. The level of inclusiveness of agricultural in Russian regions in the 2017 year. 
We can see that 8 regions have the best value of the Index (The darker the color of the region the higher the level of inclusivity). It is possible to assume that there is no association between the climate and the value of the index. There are high-level of indexes on the East and West, North and South. Regions that are successful in agriculture often have low Index values. This is largely due to the negative impact on the natural environment of agriculture in these regions, the high level of production concentration and the increased debt burden of producers, and some other factors.

Table 4. Number of regions by the Index value.

\begin{tabular}{cccc}
\hline \multirow{2}{*}{ Group of regions } & Number of regions & From & Index value \\
& & 2.87 & To \\
\hline I & 18 & 3.20 & 3.19 \\
II & 22 & 3.37 & 3.37 \\
III & 21 & 3.55 & 3.54 \\
IV & 8 & 3.73 & 3.72 \\
V & & & 4.27 \\
\hline
\end{tabular}

If we look at the best and the worst regions according to inclusive development, we can see that environmental sustainability remains the most neglected of the three groups of indicators. The best regions have a high level in all of these three groups of indicators.
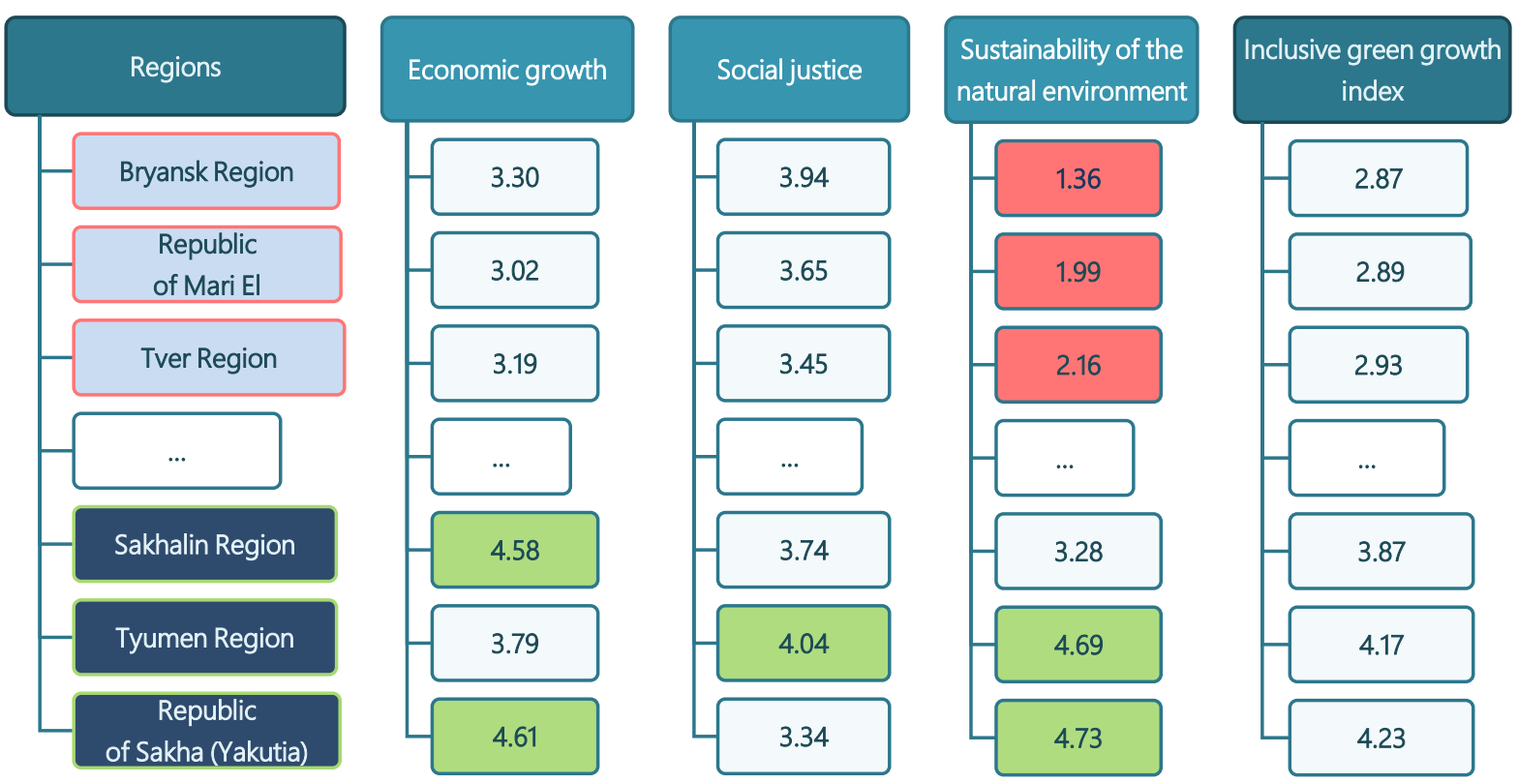

Figure 4. Inclusive Green Growth Index in three the worst and the best regions.

If we take the worst region, we can see that in economic growth the region has a lot of problems. Succeeded in agricultural production the region not sustainable and has a high level of concentration and debt. In addition, there are some problems with social justice, air pollution, and methane emission. In general, focusing on the sustainability of the natural environment indicators is the top priority for the regions. As you can see, analysis of indicators enables to set development priorities and align investment decisions with broader sustainability objectives.

Consider the region that occupies the last position in the ranking - the Bryansk region. This is an agricultural region that has received significant investments in the development of agriculture in recent years (2.5 times more than in Russia on average). The Inclusive green growth index equals 2.87 . It is the last position in our rating. Economic growth is position 67. 


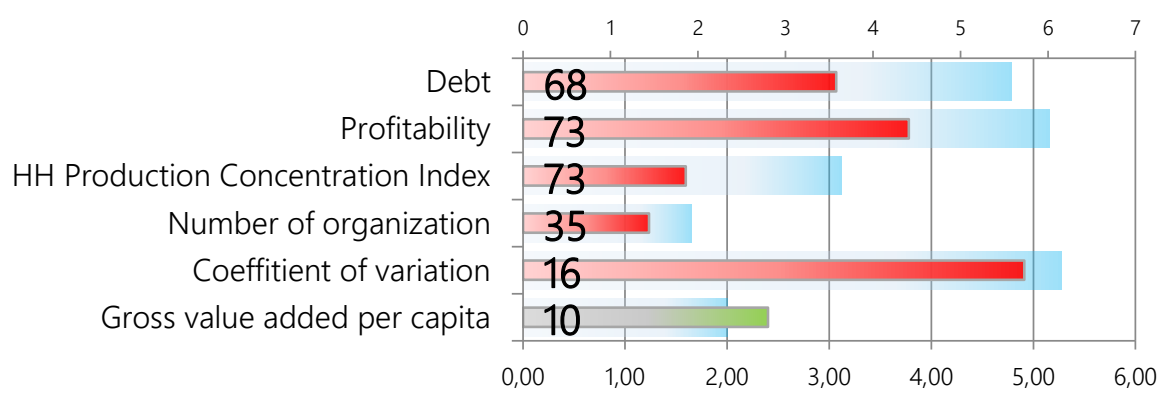

An average value $\square$ The value of the indicator

Figure 5. Values of economic growth indicators in the Bryansk region.

Having high values of gross value added per capita, having a high level of state support, the region has a high level of debt, a low level of profitability (largely due to specialization in the production of low-profit cattle products). It is also worth noting that the region is increasing the concentration of production, resources are increasingly consolidated in large enterprises. The Index of social justice leads the region to position 9.

Thanks to the development of agriculture in the region, a high level of employment, including in agriculture, is achieved a high level of wages relative to the values of the average in Russia.

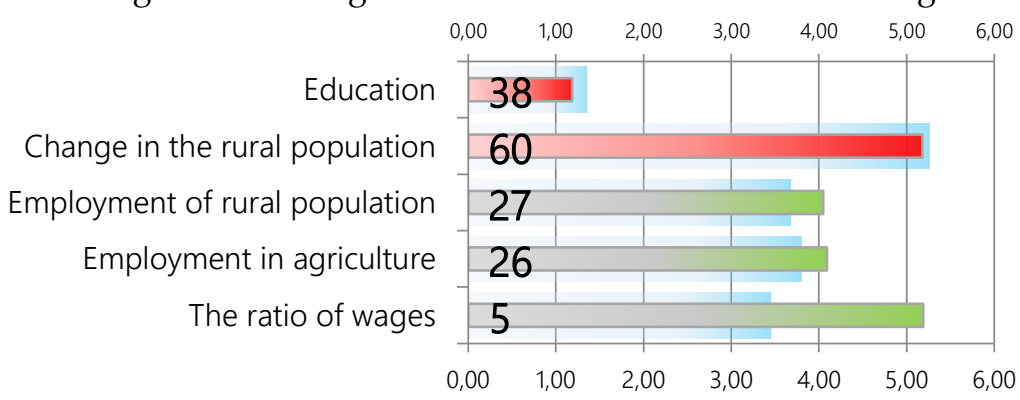

Figure 6. Values of social justice indicators in the Bryansk region.

Special problems for the region developing agriculture arise in the field of environmental protection. We see that air pollution and methane emissions are high (the region specializes in veal meat production). Thus, the regional authorities will have to solve the identified problems in order to increase the sustainability of the region's economy. They should correct a model of growth in their regional agriculture as we know that better growth gives a better climate. (Global Commission on the Economy and Climate 2014).

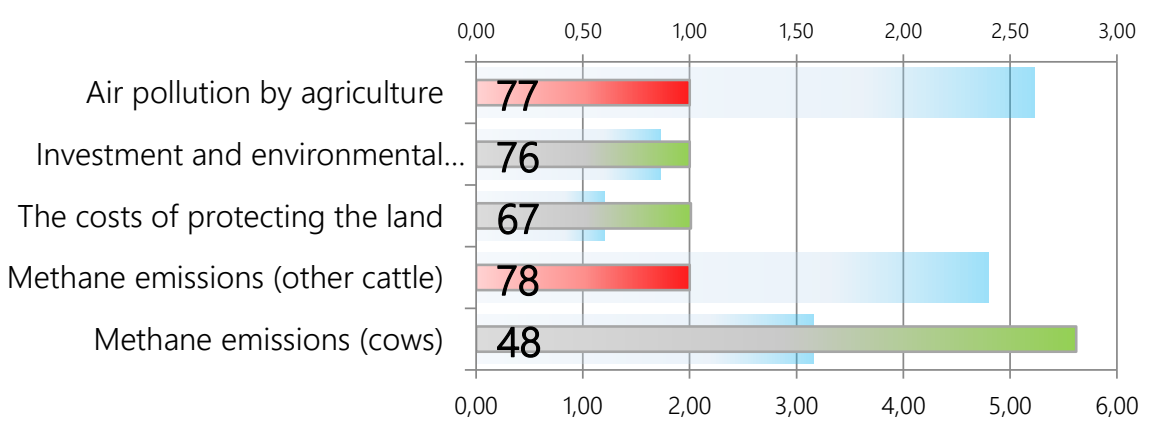

Figure 7. Values of social justice indicators in the Bryansk region.

\section{Discussion}

Thus, inclusive development is particularly relevant in the context of modern development of the Russian agricultural economy. Concentrating production in large enterprises, in parallel, there are 
problems of excessive indebtedness of enterprises, reducing their number, and high load on the environment. An inclusive model that involves other participants in the agricultural economy in production will reduce these problems and thus increase the sustainability of the Russian agricultural economy. However, it is worth noting that further detailed research is required on the factors of inclusive development, including the impact of digitalization of agriculture on its inclusiveness, the relationship between inclusivity and quality of life indicators, infrastructure development, inclusivity, and climate change issues.

\section{Conclusions}

The results of the study allow us to make the following key observations:

- Russian agriculture is developing unevenly both regions and types of producers.

- Peasant (farm) households, individual businessman and household of citizens need special support because they receive less subsidies and loans and are also an integral part of inclusive development.

- A new approach to economic growth is needed because economic, social, and especially environmental problems accumulate.

- Inclusive development will involve all regions and types of producers in the growth.

- The green inclusive growth index is a suitable measure for new quality growth.

- However, a number of key indicators are missing from official statistics, including those directly related to SDG's, which indicates the need to improve the system of indicators that track inclusivity and sustainability.

- Many Northern, Siberian, Dalnevostochny regions (such as Sakhalin Region, Tyumen Region and Republic of Sakha) that is, non-agricultural regions of Russia, showed high index values, which also indicates the emerging contradictions between green inclusive development and the current model of the agricultural economy.

- In agricultural regions (for example, the Bryansk region), problems such as rising debt, excessive concentration of production, air pollution, and methane emissions are increasing. All these problems are amplified by the implementation of the current agricultural policy of concentration of production in certain regions and certain large organizations.

- Development of agriculture on the basis of inclusiveness will provide economic green growth, reduction of poverty and injustice. In particular, this will allow Russia to develop and support small agricultural enterprises and rural areas, reduce inequality between urban and rural areas, and fully include the rural population in economic growth and well-being.

In conclusion, it is clear that there is a need for a new type of growth that helps to involve regions and all producers in development, reduce the burden on the environment, and stop the decline in the rural population. Based on new indicators inclusiveness will help change our priorities, ways of investments and thinking. Inclusiveness has a lot of factors that should be researched further.

Acknowledgments: Previous results of this study were reported at the international conference on agricultural statistics in India (ICAS VIII, New Delhi, India, 2019). All this, as well as the results of this study, would not have been possible without the moral and administrative support of my colleagues from the Department of statistics and econometrics of Russian State Agrarian University - Moscow Timiryazev Agricultural Academy.

\section{References}

Berkhout Ezra, Bouma Jetske, Terzidis Nicolaos, and Voors Maarten. 2018. Supporting local institutions for inclusive green growth: Developing an Evidence Gap Map. NJAS - Wageningen Journal of Life Sciences: 84, 5171. https://doi.org/10.1016/j.njas.2017.10.001.

Cheng Shengkui, Wang Shouyang, Liu Xu, Liu Xiaojie, and Wu Liang. 2018. Food nutrition and food security of China in a new development phase. Kexue Tongbao/Chinese Science Bulletin: 63, 1764-1774. https://doi.org/10.1360/N972018-00159.

Chiengkul Prapimphan. 2019. Uneven development, inequality and concentration of power: a critique of Thailand 4.0. Third World Quarterly: 40, 1689-1707. https://doi.org/10.1080/01436597.2019.1612739. 
Cobham Alex, and Klees Steven. 2016. Global Taxation: Financing Education and the Other Sustainable Development Goals. Background paper for the International Commission on Financing Global Education Opportunity's report. Available online: https:/www.taxjustice.net/wp-content/uploads/2016/11/GlobalTaxation-Financing-Education.pdf (accessed on 20 December 2019).

Demichev Vadim. 2018. Rating of inclusive development of the agricultural economy in Russian regions. Russian Economics online-journal: 3, 1-16.

Demichev Vadim. 2019. Sustainable development of agriculture on the basis of inclusiveness. Economics of agriculture of Russia: 6, 32-36. https://doi.org/10.32651/196-32.

GGKP (Green Growth Knowledge Platform). 2013. Moving Towards a Common Approach on Green Growth Indicators: A Green Growth Knowledge Platform Scoping Paper. Geneva. Available online: https://www.oecd.org/greengrowth/GGKP\%20Moving\%20towards\%20a\%20Common\%20Approach\%20on \%20Green\%20Growth\%20Indicators[1].pdf (accessed on 20 December 2019).

Ginige Kanchana, Amaratunga Dilanthi, and Haigh Richard. 2018. Mapping stakeholders associated with societal challenges: A Methodological Framework. Procedia Engineering: 212, 1195-1202. https://doi.org/10.1016/j.proeng.2018.01.154.

Global Commission on the Economy and Climate. 2014. The New Climate Economy Report: Better Growth, Better Climate. Washington, DC. Available online: https://newclimateeconomy.report/2015/wpcontent/uploads/sites/2/2014/08/NCE-Global-Report_web.pdf (accessed on 22 December 2019).

Inclusive development index. 2018. World economic forum in Davos: economic 16 news website. Available online: http://www.econominews.ru/mirovaja-jekonomika/524-indeks-inkljuzivnogo-razvitija2018-vsemirnyjj.html (accessed on 15 July 2018).

Inclusive green growth index. 2018. Mandaluyong City: Asian Development Bank. Available online: https://www.adb.org/sites/default/files/publication/462801/inclusive-green-growth-index.pdf (accessed on 25 December 2019).

Mdee Anna, Wostry Alex, Coulson Andrew, and Maro Janet. 2019. A pathway to inclusive sustainable intensification in agriculture? Assessing evidence on the application of agroecology in Tanzania. Agroecology and sustainable food systems: 43, 201-227. https://doi.org/10.1080/21683565.2018.1485126.

Statistical collections of the Official state statistics service of Russia. Available online: https://eng.gks.ru/folder/11427 (accessed on 12 January 2020).

Statistical yearbook of the Ministry of agriculture of Russia. Available online: http://mcx.ru/ministry/departments/departament-nauchno-tekhnologicheskoy-politiki-iobrazovaniya/industry-information/info-izdaniya-minselkhoza-rossii/ (accessed on 15 January 2020).

Struik Paul, and Kuyper Thomas. 2017. Sustainable intensification in agriculture: the richer shade of green. A review. Agronomy for sustainable development: 37, 1-15. https://doi.org/10.1007/s13593-017-0445-7.

Sun Yuhuan, Ding Wangwang, Yang Zhiyu, Yang Guangchun, and Du Juntao. 2020. Measuring China's regional inclusive green growth. Science of the Total Environment: 713, 1-10. https://doi.org/10.1016/j.scitotenv.2019.136367.

The New Climate Economy Report. 2018. Unlocking the inclusive growth story of the 21st century. Available online: https:/newclimateeconomy.report/2016/wp-content/uploads/sites/6/2018/09/

NCE_2018_ExecutiveSummary_FINAL.pdf (accessed on 15 December 2019).

Van Vuuren P. Detlef, Stehfest Elke, and Gernaat E.H.J. David. 2017. Energy, land-use and greenhouse gas emissions trajectories under a green growth paradigm. Global environmental. Change-Human and policy dimensions: 42, 237-250. https://doi.org/10.1016/j.gloenvcha.2016.05.008.

Ziankova Inha, Lisichonak Alena, and Yemialyanau Aliaksandr. 2019. Development of inclusive society with the instruments of "green" economy and education. Tehnologija. Resursi - Environment, Technology, Resources: 1, 353-358. https://doi.org/10.17770/etr2019vol1.4057.

Zinchenko Alexsey. 2016. Agriculture of Russian regions based on the results of the all-Russian agricultural census of 2016. Izvestiya of Timiryazev Agricultural Academy: 2, 125-135. 